\title{
Breandán Mac Suibhne, The End of Outrage: Post- Famine Adjustment in Rural Ireland
}

\section{Heather Laird}

\section{(2) OpenEdition \\ 1 Journals}

Édition électronique

URL : https://journals.openedition.org/etudesirlandaises/8716

DOI : 10.4000/etudesirlandaises.8716

ISSN : 2259-8863

\section{Éditeur}

Presses universitaires de Caen

\section{Édition imprimée}

Date de publication : 31 décembre 2019

Pagination : 167-170

ISBN : 978-2-84133-964-8

ISSN : 0183-973X

\section{Référence électronique}

Heather Laird, "Breandán Mac Suibhne, The End of Outrage: Post-Famine Adjustment in Rural Ireland », Études irlandaises [En ligne], 44-2 | 2019, mis en ligne le 06 mai 2020, consulté le 14 novembre 2022. URL : http://journals.openedition.org/etudesirlandaises/8716 ; DOI : https://doi.org/10.4000/ etudesirlandaises.8716

\section{(c) (i) (2) (2)}

Creative Commons - Attribution - Pas d'Utilisation Commerciale - Partage dans les Mêmes Conditions 4.0 International - CC BY-NC-SA 4.0

https://creativecommons.org/licenses/by-nc-sa/4.0/ 
identified, its value assessed, and official recognition by the Irish state is considered. Hay concludes with an analysis of the state's awarding of service pensions and / or medals to former members, and provision of financial compensation to dependants of fallen members, the ultimate recognition.

In her prior groundbreaking research, Hay had underlined how "adolescence" had been discovered during this transformative epoch, and demonstrated how the Fianna were expected to promote Irish culture in language, sport, theatre and music. But they were equally imbued with the propaganda of the age which highlighted a moral dichotomy between Ireland and degenerate and debased British people. Fianna print propaganda promoted an idealised image of Irish nationalist youth, stressing patriotism combined with morality. Revolutions are won by feats of arms, but fuelled by ideology. Beyond this lofty concept, which in established nations also sent millions of young men to early graves, many Fianna dutifully smuggled weapons, served as dispatch carriers and orderlies, gathered intelligence, but also built barricades, commandeered bikes, raided shops and vans in the light of day, obstructed communications, and were willing perpetrators of political violence. Overall the book provides a robust and comprehensive history of a movement whose activities encompassed both friends and families, touched by tragedy, or proudly watching bayonet fighting at an aeraíochtaí (outdoor festival). Students, and an international audience, will welcome the constant contextualisation within the bigger historical picture. The perspective is balanced, and foibles are documented. Na Fianna Eireann and the Irish Revolution fills a major gap in conventional Irish history, and will facilitate adaptations for secondary schools, allowing adolescents of the future to engage with a far more relevant strand of history than high politics.

Sylvie KLEINMAN

\section{Breandán Mac Suibhne, The End of Outrage: Post-Famine Adjustment in Rural Ireland, Oxford, Oxford University Press, 2017, 319 p.}

This is a rare publication in that it is both a thoroughly-researched scholarly text and an invitation to the reader to take an imaginative leap. Through a detailed account of an incident that took place in West Donegal in the mid-1850s, we learn about a key transitionary period in Irish history. But the book is much more than an analysis of a historical moment; rather it encourages us to cross a chasm of understanding and worldviews so that, even if only tentatively and momentarily, we see through the eyes of the people who populate its pages. That said, the depth of that chasm is never elided. One of the many strengths of The End of Outrage is that it demonstrates the profound differences between our way of thinking and being and that of some of those whose lives it so eloquently describes while also asking us to place a creepie (bogwood stool) in front of the fire so that we can sit for a while in their company. 
The End of Outrage opens with a recreation of Oíche Shamhna in 1856, including the ritual that brought Halloween festivities at that time to a conclusion: the loading of the fire with turf and the arranging of creepies in front of it so that the dead felt welcome to visit whilst those of the house slept. Notwithstanding an almost anthropological concern in such passages with accurately capturing a community at a particular juncture, one of Mac Suibhne's priorities in the book as a whole is to demonstrate that this society was neither homogenous nor static, but in transition even before the Famine. Population fluctuations, increased state control, language shifts, greater integration into the periphery of the world economy and, perhaps most importantly for this book, a growth in inequality within the Catholic portion of the population and a loosening of the cultural ties that bound it are just some of the factors effecting change within it. But key to The End of Outrage is the conviction that while many of these factors were outside the control of those upon whom they impacted, this was an internally-dynamic community that made choices as to how it would respond to them. Moreover, though Mac Suibhne demonstrates considerable empathy when discussing these choices, particularly when made by the more disadvantaged members of that community, he never shies away from their repercussions.

Mac Suibhne reveals himself in The End of Outrage to be on a par with the best of storytellers in $19^{\text {th }}$-century Ireland around whose firesides neighbours would nightly congregate. The incident he relates has two main players: a schoolteacher named Patrick McGlynn who turns informer on members of the secret political combination known as the Molly Maguires, and James Gallagher, a would-be rancher or large cattle-farmer who is targeted by the Mollies. We learn of McGlynn first, but Gallagher is by far the most compelling of these self-serving individuals. Gallagher is closer to the "modern" Irish than many of his contemporaries, as Mac Suibhne is at pains to point out, in that his advancement in society is dependent on his disregard for older conventions and his willingness to benefit from that which is disadvantaging others. He is, quite simply, a man of the coming times. The rundale system of landholding, which ensured that each tenant had access to a range of land types, had recently been replaced in the Beagh district of West Donegal by compact or squared farms. Gallagher's family had a larger holding under rundale than others in the locality, so it was only to be expected that this holding would also be bigger after the transition. But Gallagher is more temperamentally suited to the ideological shift that accompanied the squaring of holdings - that henceforth every man would only be accountable for his own portion - and takes advantage of this transformation in land-systems and the misfortunes of neighbours to expand his holding substantially. Those from whose adverse circumstances he benefits include forebears of the author; he acquires a substantial portion of land from one of these, Nancy Sweeney, when she falls into arrears and he assists in the paying of her rent. Keen that his upwardly-mobile status be noted by all in Beagh, he moves to a house conspicuously located at the centre of the townland. The disparity between his circumstances and those of the subtenants on the land formerly held by Nancy Sweeney, whom he now proceeds to evict so that he can 
populate his holding with cattle, would have been obvious to all in the locality. It is in defence of these subtenants and Gallagher's own father, who has been reduced to begging by his son's failure to follow customary practices regarding familial responsibilities, that the Molly Maguires turn their attention on Gallagher. The first step, as was generally the case with such secret combinations, was the sending of a threatening letter. This is where McGlynn comes into the story. He is a reluctant member of a local lodge of the Mollies and highly literate. Hence, he is asked to pen the letter. When it becomes clear that Gallagher, a notoriously arrogant man, has no intention of succumbing to the Mollies' threats and that an attack is imminent, McGlynn is justifiably concerned that, as the writer of the letter, he will be viewed as an accessory to Gallagher's attack and possible murder. This, combined with hope of financial reward, compels him to contact the police. The result is the conviction of five men, on very scant evidence, for membership of an illegal combination.

Like all good storytellers, Mac Suibhne is attuned to both the nuances and broader implications of the tale he tells. We may empathise with the Molly Maguires in their defence of the most impoverished of tenants threatened with landlessness and an elderly man who, notwithstanding his son's newly-acquired wealth, ends up in a poorhouse, but those involved in anti-state activities are shown in The End of Outrage to also make choices in the post-Famine period, the end result of which is an Ireland in which James Gallagher would have felt very much at home. Thus the "outrage" referenced in the book's title is both acts committed by groups like the Mollies that were considered offences under the official legal system and a sense of moral indignation about the fate of the rural poor that lessens in the latter half of the $19^{\text {th }}$ century. With regard to broader implications, perhaps more could have been said about the human cost, and economic and environmental implications of the post-Famine "corn-to-horn" transition, as it is sometimes called, with "corn" standing in for tillage more generally, that Gallagher was so keen to cash in on. That said, the repercussions of Ireland's transformation in the latter half of the $19^{\text {th }}$ century into a colonial cattle pasture, including the country's current over-dependence on the beef industry, are more topical in a post-Brexit scenario than it would have been at the time of The End of Outrage's composition. Moreover, it seems petty to critique a book that is already so rich for what it might have dealt with in more depth.

This richness is attributable not only to the wide range of topics that Mac Suibhne links to the stories of John Gallagher, Patrick McGlynn and those whose lives they impacted on, but to the scholars he draws on to shape the conceptual apparatus of the book, most notably David Lloyd and Primo Levi. Lloyd's influence is most evident in references to "futures lost". On a micro level, this is an allusion to the fortunes of those who suffered most from Gallagher's heightened individualism: the subtenants on Nancy Sweeny's land whose futures he quite literally robs. But the term also encourages us to think counterfactually and speculate on futures grounded in a more communal way of thinking and being that could potentially have emerged from moments past. Here we think of Lloyd's assertion throughout much of his work that the only way to ensure that a future society is more than a mere 
extrapolation of present-day power is to ground it in that which has been dismissed in the past as an obstacle to progress. Inspired by Levi, Mac Suibhne's reflections on those who survived and those who thrived in bad times expand far beyond the stories of Gallagher and McGlynn. Ultimately, we are forced to acknowledge that notwithstanding the role of the Famine in providing a relatively cohesive narrative of what was done to the Irish nation in the mid- $19^{\text {th }}$ century, many of us currently living in Ireland are ourselves the descendants of those who survived and possibly even thrived in Ireland's worst of times. Thus, while this is nominally a book about the $19^{\text {th }}$ century, it has an important contemporary relevance. The End of Outrage is dedicated to the author's children and, as the concluding sentence of the Acknowledgements suggests, one of the shadows hanging over it is another worst of times; an impending environmental catastrophe that is our legacy for future generations. But, as this book makes clear, a crisis will always be viewed by some as an opportunity to advance their own situation. Even in this coming worst of times, it may be possible for some to not only survive but thrive. The importance of books like Mac Suibhne's The End of Outrage is that they encourage us to speculate on alternative approaches to bad times that mitigate against opportunistic profiting on others' misfortune.

Heather LAIRD 